\title{
兵庫県南部地震の被害デー夕に基づく建物倒壊危険度評価法の提案 NEW METHOD FOR BUILDING COLLAPSE RISK ASSESSMENT BASED ON DAMAGE DATA DUE TO THE 1995 HYOGOKEN-NANBU EARTHQUAKE
}

\author{
村尾 修*, 田中宏幸**, 山崎文雄 ${ }^{* * *}$, 若松 加寿江 ${ }^{* * * *}$ \\ Osamu MURAO, Hiroyuki TANAKA, Fumio YAMAZAKI \\ and Kazue WAKAMATSU
}

\begin{abstract}
Tokyo Metropolitan Government recently published "The Earthquake Area Vulnerability Assessment of Tokyo". It shows relatively dangerous zones in Tokyo. In this paper the method for building collapse risk used in this report was applied to the Nada Ward in Kobe City using building inventory before the 1995 Kobe Earthquake. The obtained "building collapse risk" was compared with the actual damage of the ward due to the earthquake and a revised method to evaluate "building collapse risk" was proposed. The new building collapse risk corresponds to the ratio of building collapse and it reflects the characteristics of buildings and grounds.
\end{abstract}

Keywords: building collapse risk, the 1995 Hyogoken-Nanbu Earthquake, building damage, Tokyo, Nada Ward, GIS

建物倒壊危険度, 兵庫県南部地震, 建物被害, 東京都, 灘区, 地理情報システム

1.はじめに

兵庫県南部地震（阪神・淡路大震災）を契機に, 国, 地方自治体, 個人とあらゆるレベルで地震防災への意識が高まり，大規模かつ多 岐にわたった被害を考慮して, 被害想定を見直し, あるいは新たに 検討する気運が高まっている．各自治体で行われている地震被害想 定には様々な手法が存在する1が，それらの多くは，ある地震の発 生を仮定した上で地震動を推定し，経験的な被害関数などから地震 発生時の被害を予測するものである. 東京都でも被害想定を実施し ているが，本研究で取り上げた「東京都地域危険度測定調査」(第 4 回） 2)-4)は, これまでの被害想定とは違った角度から, 都内の地震に 対する危険度を算定したものである.これは東京都が東京都震災予 防条例に基づき， 5 年ごとに実施している調査であり，その目的は,

「都市災害に強い都市づくりの指標とする」,「震災対策事業を優先 的に実施する地域を選択する際の参考とする」，「地震災害に対する 都民の認識を深め, 防災意識の高揚に役立てる」などである. 地震 が発生することを仮定して被害を予測するという点では, 被害想定 も地域危険度評価も同じ性質のものであるが, 被害想定が特定の地 震動発生を仮定し, その地震によって生じる具体的な被害量を想定 することを目的としているのに対し, 地域危険度評価は, 被災ポテ ンシャルを地域間で比較し，相対的に危険な地域を抽出することを 目的としているという点で, その算定方法・考え方に違いがある. このため危険度の算出過程において, 特定の地震は考慮されておら
ず，対象地域全体で震源位置に依らない地震動が仮定されており， 複雑な解析を必要とする被害想定に比べ, 比較的簡単な算定式と町 丁目単位での地盤や建物のデー夕等を用いて決定される. 東京都に よる現行の手法は, 東京都の特性に合わせて分類された地盤や建物 について, 専門家の判断に基づく危険性ウェイトが設定されており, 危険度を被害率ではなく被害総量という意味でとらえている.

本研究の目的は, 東京都地域危険度の中の建物倒壊危険度評価方 法を検討し，モデルとしての簡易性を保ちつつ，より一般的な建物 倒壊危険度評価法を提案することにある. そのために，ここでは東 京都による手法を神戸市灘区に適用し，その結果求められた建物倒 壊危険度と兵庫県南部地震により実際に発生した建物被害を比較す る. さらに確率論的な概念も取り入れ, 地盤や構造物の地震に对す る危険性ウェイトの設定方法を具体的に定義し，新建物倒壊危険度 の評価手法を提案する.

\section{2. 東京都の建物倒壊危険度}

東京都により発表された「建物倒壊危険度」 2)-4)は, 地震動によっ て建物が壊れたり傾いたりする危険性の度合を，建物，地盤などの 面から評価し, 他地域と比較した相対的な危険の度合を単位面積当 たりの被害総量という観点から 5 段階に分類したものである．建物 倒壊危険度決定までの過程を図 1 に示す.

分類項目は表 1 の通りである. 建物については, 構造別, 年代別,
* 東京大学生産技術研究所 助手・博士 (工学)

** 東京大学大学院工学系研究科 大学院生

*** 東京大学生産技術研究所 助教授・工博

**** 東京大学生産技術研究所 研究員 ·工博
Research Assoc., Institute of Industrial Science, University of Tokyo, Dr. Eng. Graduate Student, Graduate School of Engineering, University of Tokyo Assoc. Prof., Institute of Industrial Science, University of Tokyo, Dr. Eng. Research Fellow, Institute of Industrial Science, University of Tokyo, Dr. Eng. 
階数により 20 に分類し，「その他」を除く 19 分類に対して耐震性 能を評価し, ウェイトとして算定式に反映させている. また建物 倒壊に最も影響すると考えられている基礎地盤については, 地震 被害の発生しやすさの観点から地形・地質によって 10 種類に分類 している. さらに地盤による影響を補完するために, 液状化の可 能性, 大規模造成地, 埋立地, 急傾斜地の有無についても考慮さ れている. 各ウェイトは 6 人の専門家により，0 と 1 の間で危険 なものほど 0 に近くなるよう 6 パターン設定されている.これら を基に，あるパターン $n$ における建物ごとの倒壊危険量 $Q_{k n}$ は次 のように算定される

$$
Q_{k n}=D_{k}\left(1-W_{k n} \cdot U_{k n}\right) \quad(k=1-19: \text { 建物分類 })
$$

ここでパターン $n(n=1-6)$ における各パラメータは，それぞれ $Q_{k n}$ : 建物ごとの倒壊危険量（棟数/単位面積）， $D_{k}$ : 建物棟数密 度 (棟数/単位面積), $W_{k n}$ : 耐震性能门エイト (無次元量), $U_{k n}$ : 地盤特性ウエイト（無次元量）である．地盤特性ウエイト $U_{k n}$ は 次式により算定される.

$$
U_{k n}=u_{1 n} \cdot u_{2 n} \cdot u_{3 n} \cdot u_{4 n} \cdot u_{5 n}
$$

パターン $n$ におけるウェイトの各要素は, $u_{1 n}$ : 基礎地盤, $u_{2 n}$ : 液 状化, $u_{3 n}$ : 大規模造成地, $u_{4 n}$ : 埋立地, $u_{5 n}$ : 急傾斜地である.

上記の建物ごとの倒壊危険量 $Q_{k n}$ を次式のように合算したもの が, パターン $n$ における町丁目の建物倒壊危険量 $Q_{i n}$ となる.

$$
Q_{i n}=\sum_{k=1}^{m} Q_{k n}
$$

$(m=19:$ 建物分類数)

(1)，（2）式により算出した 6 種のパターン $(n=1-6)$ ごとの建物 倒壊危険量 $Q_{i n}$ を標準偏差の 3 倍で除して規準化し, 平均したも のが最終的な建物倒壊危険量 $Q_{i}$ （無次元量）となる（以下，この $Q_{i}$ を建物倒壊危険量と呼ぶこととする).そして建物倒壊危険度 $Q$ は， $Q_{i}$ を大きいものから順に 5 段階に割り当てたものである.

各ウェイトの設定基準2)は, 過去の地震被害事例および耐震基準 改正の時期等が考慮されているが，それぞれの専門家のウェイトを 比較してみると, 6 つのパターンに大きな差異が存在しており, ウ エイト付けの困難さが窺える．東京都の建物倒壊危険度は，被害率 ではなく被害総量という意味でとらえているため, 建物棟数密度が 建物倒壊危険量算定に最も影響を与えており，区部（平均建物棟数 密度 3,460 棟 $/ \mathrm{km}^{2}$ ) の建物倒壊危険度が多摩地区 (平均建物棟数密 度 830 棟 $/ \mathrm{km}^{2}$ ) と比較して圧倒的に高くなっている. 本研究では東 京都の方法とは別の観点から，一棟一棟の建物の特性とそれが立地 している地盤に起因する建物倒壊危険度について検討する.

\section{3. 東京都の方法による灘区の建物倒壊危険度と実被害との比較 （1）灘区の建物特性と地盤特性}

東京都の方法を用いて，灘区の 353 町丁目についてそれぞれの地 盤特性と建物を分類した. ただし北部山簏部は図中省略している.

建物の分類にあたっては，兵庫県南部地震の直後に行った神戸市 による建物被害調查テータら)を使用した．灘区における木造， RC 造， $\mathrm{S}$ 造, 軽量 $\mathrm{S}$ 造の割合は，それぞれ $74.6 \% ， 12.7 \% ， 7.0 \% ， 4.2 \%$ とな つており，木造建物の比率が全体の $3 / 4$ を占めている. 木造建物の 中では，住宅，店舗併用住宅の割合がそれぞれ 92.7\%，7.3\%で，圧 倒的に住宅の割合が高い，各町丁目の面積は，町丁目ごとの統計資 料が入手できなかったため, GIS の機能を用いて算出した. 以上の 結果得られた建物棟数密度分布を図 2 に示す.

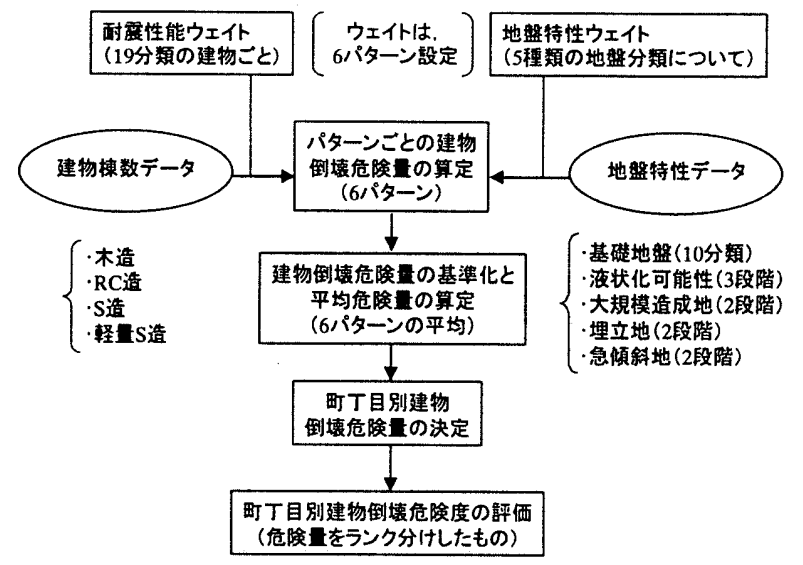

\begin{tabular}{|c|c|c|c|c|c|c|}
\hline $\begin{array}{l}\text { 分類 } \\
\text { 番昂 }\end{array}$ & 搆造 & \multicolumn{2}{|c|}{ 理類 } & $\begin{array}{l}\text { 分期 } \\
\text { 番品 }\end{array}$ & 基碐地盤分類 & 地形・地留の特得 \\
\hline \multirow{2}{*}{\begin{tabular}{|l|}
1 \\
2 \\
3 \\
4 \\
\end{tabular}} & \multirow{2}{*}{ 木造 } & 住宅 & \begin{tabular}{|l} 
昭和45年以前 \\
昭和 46 年以㦀 \\
\end{tabular} & 1 & 山地・丘陵 & 山地及ひ丘陵地 \\
\hline & & 店哺 - 併用住宅 & \begin{tabular}{|l|} 
昭和 45 年以前 \\
昭和 46 年以降 \\
\end{tabular} & 2 & 台地 1 & 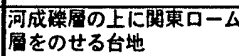 \\
\hline $\begin{array}{l}5 \\
6\end{array}$ & \multirow{5}{*}{ RC造 } & \multirow[t]{2}{*}{$1 \sim 3 F$} & \begin{tabular}{|l|} 
成和 45 年以前 \\
盼和 $46 \sim 55$ 年 \\
\end{tabular} & 3 & 台地2 & \begin{tabular}{|l} 
海成粘士・砂扁の上に関果 \\
ローム層をのせる台地
\end{tabular} \\
\hline $\begin{array}{l}7 \\
8\end{array}$ & & & \begin{tabular}{|l|} 
䧂和 56 年以降 \\
略和 45 年以前 \\
\end{tabular} & 4 & 谷底低地1 & 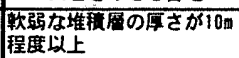 \\
\hline $\begin{array}{c}9 \\
10\end{array}$ & & $4 \sim 7 F$ & \begin{tabular}{|l|} 
昭和 $46 \sim 55$ 年 \\
昭和 56 年以隆 \\
\end{tabular} & 5 & 谷底低地2 & 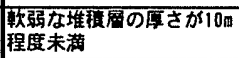 \\
\hline $\begin{array}{l}11 \\
12\end{array}$ & & \multirow[t]{2}{*}{ 8F以上 } & \begin{tabular}{|l|} 
昭和 45 年以前 \\
昭和 $46 \sim 55$ 年 \\
\end{tabular} & 6 & 沖程面 I & $\begin{array}{l}\text { 沖霜が主に河成碩からな } \\
\text { るころ }\end{array}$ \\
\hline 13 & & & 昭和 56年以㦀 & 7 & 面 2 & 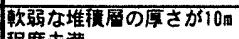 \\
\hline 14 & \multirow{3}{*}{ S造 } & \multirow{2}{*}{$1 \sim 5 \mathrm{~F}$} & 昭和 55年以前 & & Alay 2 & 程度未渵 \\
\hline 15 & & & 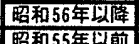 & 8 & 沖艘面 3 & 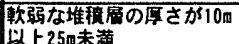 \\
\hline $\begin{array}{l}16 \\
17\end{array}$ & & 6F以上 & \begin{tabular}{|l|} 
昭和 55 年以前 \\
昭和 56 年以降
\end{tabular} & \multirow[b]{2}{*}{9} & \multirow[b]{2}{*}{ 沖提面 4} & \multirow{2}{*}{ 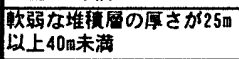 } \\
\hline \multirow{3}{*}{\begin{tabular}{|l|}
18 \\
19 \\
20 \\
\end{tabular}} & \multirow{2}{*}{ 柽S造 } & \multicolumn{2}{|c|}{ 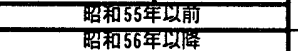 } & & & \\
\hline & & 昭和 56 䍃 & 再以及降 & \multirow[b]{2}{*}{10} & \multirow{2}{*}{ 沖䡚面 5} & \multirow{2}{*}{ 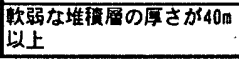 } \\
\hline & その他 & 石道, フロッ & 万道，王成） & & & \\
\hline
\end{tabular}

図 1 東京都の建物倒壊危険度決定までのフロー

表 1 東京都の建物倒壊危険度評価における建物・基礎地盤分類項目

地盤に関しては東京都と灘区とでは本質的に異なる．そのため地 盤を分類するにあたり, 山地, 台地, 沖積面などの微地形分類は土 地条件図等6)-8)により判断し, また軟弱な堆積層の厚さは, 神戸の地 盤のボーリング柱状図9に基づき, 砂・礫層では $\mathrm{N}$ 值 10 以下, 粘土 層では $\mathrm{N}$ 值 4 以下の地層を軟弱層とみなして算定した.

図 3, 図 4 に灘区の地盤特性分類の例を示す. 東京都の方法では 基礎地盤が 10 種類に分類されているが，「灘区には谷底低地の項目 に当てはまる町丁目がない」,「東京都には『軟弱な堆積層が $10 \mathrm{~m}$ を 超える沖積面』が存在するのに対し, 灘区の大部分の地域では軟弱 地盤が $10 \mathrm{~m}$ 以下であり, 町丁目単位で見た場合, 軟弱な堆積層が $10 \mathrm{~m}$ 以上という項目（沖積面 3，4，5）に当てはまる地域がない」 などの理由により，5種類の分類となった. その中で六甲山町，摩 耶山町等,「山地・丘陵」と分類された山麓地区を省略したものを図 3 に示す. 液状化可能性については, 兵庫県南部地震によって実際 に液状化が発生した地区8)を液状化可能性大として判定した。 それ 以外の地区では大規模な液状化は起こらなかったため, 全て液状化 可能性なしと判定した. 大規模造成地の分類 (図 4)においては,「人 工地形」が町丁目の $50 \%$ を占めるか否かで判定した. 埋立地, 急傾

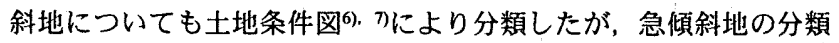
は,「極急斜面」の存在の有無で判定した. また埋立地は灘区におい て液状化可能性のある地区と合致した.

(2) 灘区の建物倒壊危険度

（1）のように建物・地盤を分類集計し，東京都の算定式に適用した 結果, 灘区内の各町丁目における建物倒壊危険量が算出された. 䔩 
区の建物倒壊危険量は平均的に見て東京都の建物倒壊危険量よりも 少し高い程度であった. 算出された建物倒壊危険量を 5 段階にラン ク分けした建物倒壊危険度を图 5 に示す, 比率割当は, 実被害と容 易に比較できるよう全壊率の 20\%間隔に分類される町丁目の数に合 わせた，例えば，全壊率 80-100\%の町丁目数と建物倒壊危険度 5 の 町丁目数が同数となっている.

建物倒壊危険度の分布は非常に疎らなものになっており，建物倒 壊危険度 1 の町丁目と建物倒壊危険度 5 の町丁目が隣り合っている 個所が随所に見られる. また，図中北西部（王子公園駅東側一帯） に建物倒壊危険度 5 の地域が多く集中しているが，これは建物棟数 密度の高い地域（図 2）と一致する，液状化可能性の高い臨海部の 埋立地域では建物倒壊危険度が 1 となっているが，これは当該地域 の建物がその広さに比べて少ないためである. 建物倒壊危険度 1 の 町丁目は，その他に北部の丘陵地帯にも広がっている.

\section{（3）兵庫県南部地震による難区の被害概要と地震動の推定}

灘区では, 兵庫県南部地震によって死者 933 人, 火災総数 22 件が 発生した ${ }^{10)}$. またこれまでに行ってきた分析5によれば，全焼建物が 474 棟, 全壊建物が 13,196 棟, 半壊建物が 6,053 棟, その他の建物 が 11,257 棟であった. 特に, 過半数の木造建物が全壊しており, 全 木造建物の 74\%が全半壊の判定を受けている. また木造建物は灘区 における全建物の 75\%を占めているため, 木造建物の被害率は, 灘 区全体の被害率に多大な影響を与えている。
過去に建物被害から推定した灘区の最大速度（PGV）分布 ${ }^{11)}$ １2） を図 6 に示す．この分布は, 翠川・藤本 ${ }^{13)}$ 濐石の転倒から推定し た最大速度分布とも類似しているものである. 兵庫県南部地震にお いて震度 7 の帯 $\left.{ }^{14}\right)$ 之呼ばれている阪急電鉄神戸線と JR 線に挟まれた 地域で，一様に地震動が大きくなっているのが確認できる．また町 丁目単位でまとめた建物の全壊率分布5)（図 7）から, 震度 7 の帯に 沿って，被害が顕著に表れていることがわかる，全壊率 20\%以上の 町丁目のほとんどは, 阪急電鉄神戸線以南に集まっており, 同線の 北側では，ほとんど被害がなかった。

(4) 建物倒壊危険度と実被害との比較

ここでは，(2)で得た東京都の方法による灘区の建物倒壊危険度と 兵庫県南部地震による実被害とを比較する. 図 5 と図 7 を比較する と，実被害が大きかった震度 7 の帯内でも建物倒壊危険度の小さい 地域が多数存在し, また北西部 (王子公園駅東側一帯) には実被害 が少ないにもかかわらず建物倒壊危険度の大きい地域がある.

東京都の力法による建物倒壊危険度は第 3 回調査 ${ }^{15)}$ と同様に被害 総量を見積もったものと考えられるため, そのような観点から，建 物倒壊危険量と実被害の比較を数量的に行ったものを図 8 に示す. 縦軸には建物倒壊危険量, 横軸は建物倒壊危険量に対応した値とし $\tau$, 全壊および全半壊建物棟数密度（町丁目内の建物被害棟数/町 丁目の面積）をとっている. また PGV の大きさに応じて図中のシン ボルを区別して示している. 全体的に見て全壊建物 $\left(\mathrm{R}^{2}=0.292\right)$ よ

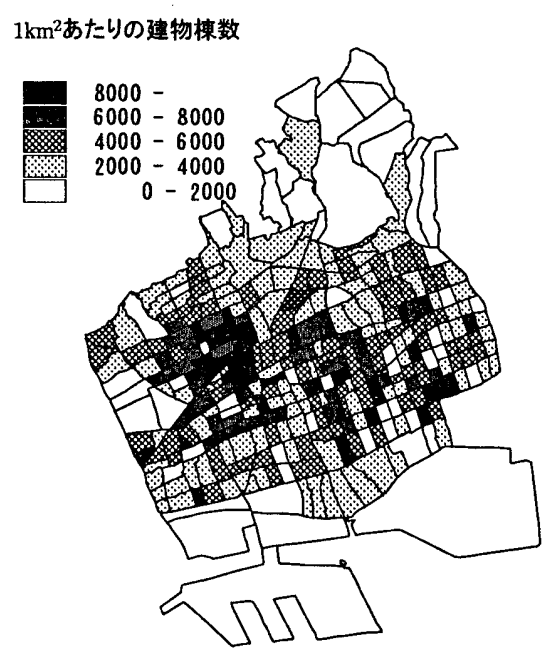

図 2 灘区の建物棟数密度分布

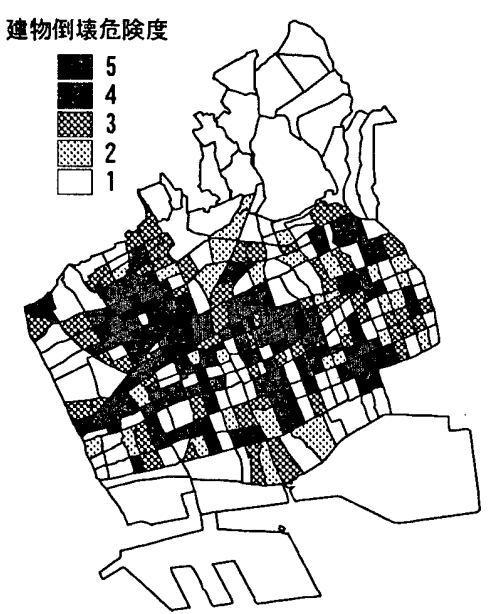

図 5 灘区の建物倒壊危険度

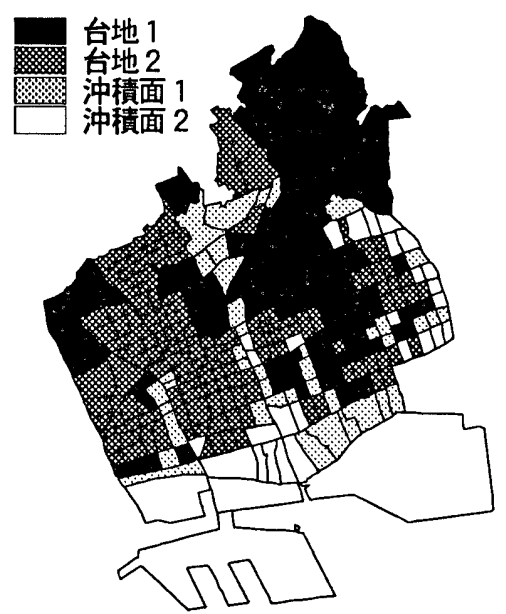

図 3 灘区の基礎地盤分類

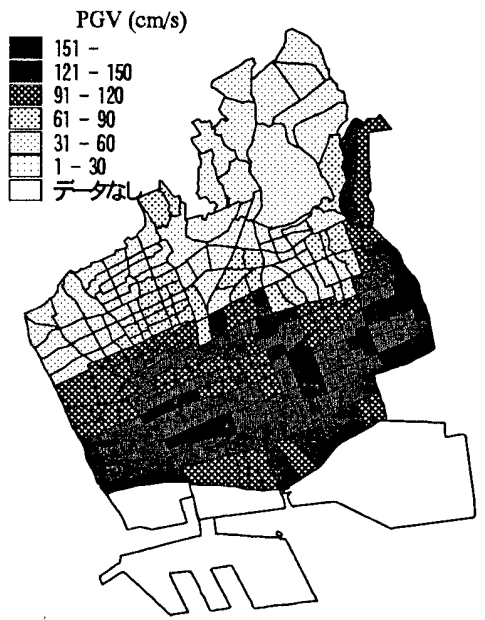

図 6 灘区の町丁目単位の推定 PGV



図 4 灘区の大規模造成地占有率



図 7 灘区の建物全壊率 
りも全半壊建物（ $\mathrm{R}^{2}=0.765 ）$ の方が相関が高くなっていることがわ かる. 全壊建物との関係をみると, PGV の弱いものほど分布の傾 きが急になっている.つまり小さな被害に対して大きな建物倒壊危 険量が見積もられていることであり，同じ建物倒壊危険量でも PGV が大きい方が実被害は大きかったということを示している.

兵庫県南部地震の際には，建物倒壊により多くの死者が発生し， それらは火災など 2 次災害の原因にもなっていた. 被災ポテンシャ ルとしての建物倒壊危険度は, 全壊率に対応するものであることが 望ましいと考えられる.ここで, 図 9 に, 全壊率と建物倒壊危険量 との比較を示す.ここでも PGVについてシンボルを変えて示してい る.これを見る限り, 全壊率と建物倒壊危険量との間に明確な相関 は見られない.しかし PGV の大きさに応じて分布の特徵が見られる。 これは推定された地震動 ${ }^{22}$ が, 建物被害率に基づいているため, PGV と全壇率の相関が強くなっているためである.

一方, 図 8, 图 9 と同様の図を用いて, 基礎地盤に関しての分布 の相関も調べてみたが, 関係性が認められなかった.

（2）で建物倒壊危険度 5 の集中している地域が, 建物棟数密度の高 い地域と類似していることを述べた，建物倒壊危険量と基礎地盤の 間に明確な相関がないことから，建物倒壊危険量が建物橧数密度を 主因として決定されていることがわかる.これは建物棟数密度と建 物倒壊危険量とを比較した図 10 からも明らかである. 前節において, 東京都の建物倒壊危険度算定における建物密度の影響を指摘したが， 灘区においては更に顕著であると思われる，その理由として，台地 1，2，沖積面 1，2 で設定された地盤特性ウェイトには大差がなく， 式(1)における建物槙数密度 $D_{k}$ の寄与度が著しく高くなってしまっ
たことが考えられる. そのため, 図 11 に示したように建物棟数密度 と実際の全壊率の間には，相関が見られない．したがって全壊率に 対応する指標として建物倒壊危険度を考えるとき，建物棟数密度の 影響を取り除く必要がある. ある町丁目において全壊率が高いとい うことは，地震動入力を一定と考えた場合，その町丁目内での地盤 条件を含めた建物の倒壊可能性が高いということである．行政が震 災対策事業によって改善すべき地域を選択する場合に，全壊率に対 応した指標を用いることが出来ればより有効であると思われる. 次 節では，以上のことを踏まえた評価法として，東京都の建物倒壊危 険度評価法の簡易性を保ちながらも，建物棟数密度の影響を取り除 き，確率論的な概念に基づくウェイト設定を用いた，より実被害に 適合する評価法を提案する.

\section{4. 実被害データに基づく新建物倒壊危険度評価法の提案 \\ (1) 建物存在率とマトリクスタイプのウェイト設定}

ここでは，(1)危険度を実被害における全壊率に対応するものとし て評価する，(2)建物特性と地盤特性に関する実被害データに基づく ウェイトを設定する，の 2 点について検討し，新建物倒壊危険度評 価法について提案する.

まず，東京都建物倒壊危険度に関する式(1)において，「 $D_{k}$ ：建物 棟数密度」を「 $N_{k}$ : 建物存在比率」とする（例 : 木造建物の存在比 率=町丁目内の木造建物棟数 /町丁目内の全建物棟数).これにより， 全壊率に対応した建物倒壊危険度が求められる。

次にウェイトの設定を見直す（1)式のように, 東京都の方法では, 建物酎震特性と地盤特性がそれぞれ独立のものとして設定されてい

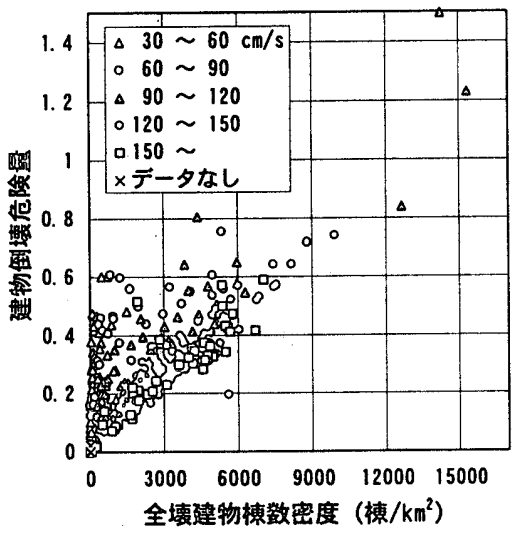

図 8 全壊・全半壊建物棟数密度と建物倒萝危険量の比較



図 9 全壊率と建物倒壊危険量の比較



図 12 灘区の地盤分類

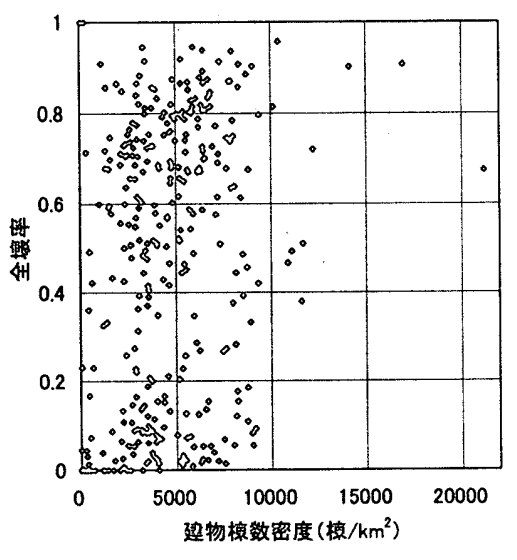

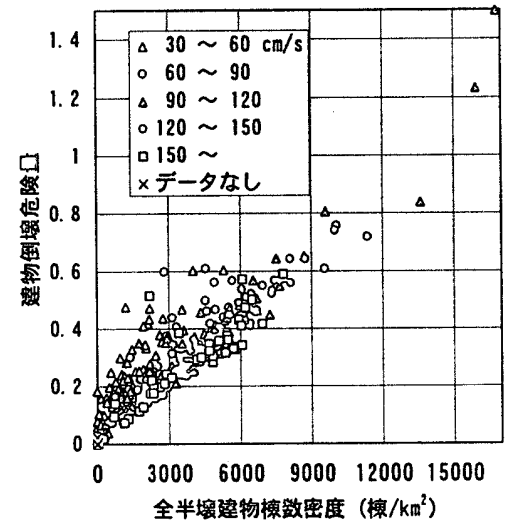

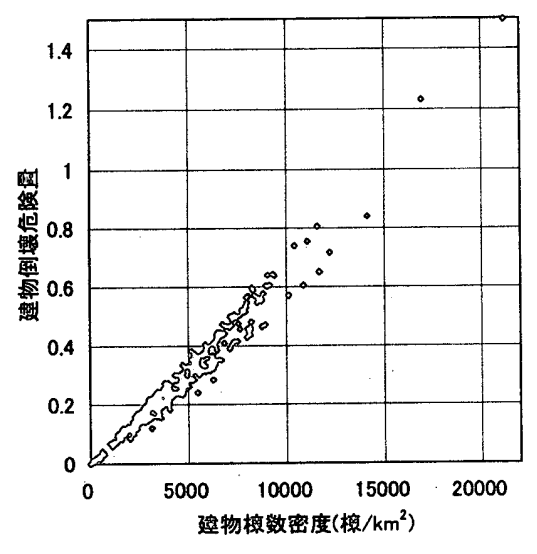

図 10 建物槙数密度と建物倒壊危険量の比較
図 11 建物植数密度と全壊率の比較

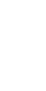


るが，まずは，その有效性について検討する。

建物耐震特性は，これまでに構築した建物被害関数16)に基づき， 構造・建築年代から分類している．また地盤分類については，灘区 の地盤をより正確に表すものとして，著者らの研究グループが過去 に行った西宮市や尼崎市の地盤分類 ${ }^{17)}$ ，18）上同様に，土地条件図6)７) ボーリング柱状図9)等から, 山地, 段丘, 扇状地, デル夕, 埋立地 の 5 つの表層地盤タイプに分類した（図 12）。ただし，臨海部の埋 立地 4 町丁目に関しては大規模な液状化が発生し，それらが建物被 害に大きな影響を与えているため，対象地域から外してある.

表 2 は, 各地盤・建物の分類項目ごとの建物全壊率と規準化数値 を示したものである．規準化数値とは，1982-94 年に建造された RC 造建物の全壊率を 1.0 として, 各項目で, 被害を受ける確率の比率 がどれ位かということを表している．建物分類項目ごとに地盤項目 を比較すると，それぞれ規準化数值の変動が大きく，地盤による全 壊率の影響は一定ではない。これは建物耐震特性と地盤特性とのウ エイトがそれぞれ独立して設定できないことを示している.

したがって，ここでは表 2 の全壊率をマトリクスタイプの地震危 険性ウェイトとして取り扱う。このウェイト設定によって建物耐震 特性と地盤特性との関係を表現することが可能となり，より実際の 地震被害に近い建物倒壊危険度が得られる。なお，ここで設定した 危険性ウエイトは兵庫県南部地震の経験に基づいており，この地震 による地震動分布や阪神地域の建物特性の影響を含んでいる.

(2) 新建物倒壊危険度

新たな指標は表 2 の全壊率を危険性ウエイトとして扱かっており，

表 2 分類項目ごとの建物全壊率（\%）と規準化数値

\begin{tabular}{|c|c|c|c|c|c|c|c|c|c|c|}
\hline \multirow{2}{*}{\multicolumn{3}{|c|}{ 分数 }} & \multirow{2}{*}{\multicolumn{2}{|c|}{ 山地 }} & \multirow{2}{*}{\multicolumn{2}{|c|}{ 段乒 }} & \multicolumn{2}{|c|}{ 㡍状地 } & \multicolumn{2}{|c|}{ テル夕 } \\
\hline & & & & & & & & & & $\overline{4}$ \\
\hline 豐造 & 年代 & 番号 & |全溒率 & $\begin{array}{l}\text { 規準化 } \\
\text { 数值 }\end{array}$ & 全埭率 & $\begin{array}{c}\text { 规隻化 } \\
\text { 化数磌 }\end{array}$ & 全媴率 & $\begin{array}{c}\text { 規集化 } \\
\text { 数值 }\end{array}$ & 全厪率 & $\begin{array}{c}\text { 规準化 } \\
\text { 数值 }\end{array}$ \\
\hline \multirow{5}{*}{ 木造 } & -1951 & 1 & 0.9 & 1.9 & 19.6 & 19.7 & 76.0 & 11.2 & 87.8 & 10.1 \\
\hline & $1952-61$ & 2 & 20.1 & 40.7 & 12.5 & 12.5 & 76.9 & 11.3 & 77.1 & 8. 9 \\
\hline & $1962-71$ & 3 & 11.0 & 22.4 & 11.1 & 11.1 & 74.0 & 10.9 & 79.4 & 9.1 \\
\hline & $1972-81$ & 4 & 8.0 & 16.2 & 4.1 & 4.1 & 50.2 & 7.4 & 48.9 & 5.6 \\
\hline & $1982-94$ & 5 & 3.8 & 7.6 & 0.8 & 0.8 & 24.2 & 3.6 & 26.2 & 3.0 \\
\hline \multirow{3}{*}{ RC造 } & -1971 & 6 & 1.7 & 3. 5 & 6.0 & 6.0 & 29.5 & 4. 3 & 29.0 & 3.3 \\
\hline & $1972-81$ & 7 & 2.6 & 5.3 & 1.2 & 1.2 & 17.5 & 2.6 & 31.3 & 3.6 \\
\hline & $1982-94$ & 8 & 0.5 & 1.0 & 1.0 & 1.0 & 6.8 & 1.0 & 8.7 & 1.0 \\
\hline \multirow{3}{*}{ S造 } & -1971 & 9 & 5.7 & 11.6 & 5.7 & 5.7 & 54.2 & 8.0 & 40.0 & 4.6 \\
\hline & $1972-81$ & 10 & 0.0 & 0.0 & 6.7 & 6.7 & 41.5 & 6.1 & 18.6 & 2.1 \\
\hline & $1982-94$ & 11 & 0.0 & 0.0 & 2.6 & 2.6 & 13.7 & 2.0 & 13.1 & 1.5 \\
\hline \multirow{3}{*}{ 轱S造 } & -1971 & 12 & 2.9 & 5.9 & 3.7 & 3.7 & 62.5 & 9.2 & 50.0 & 5.7 \\
\hline & $1972-81$ & 13 & 1.7 & 3.4 & 4.3 & 4.3 & 15.4 & 2.3 & 10.0 & 1.1 \\
\hline & $1982-94$ & 14 & 1.2 & 2.5 & 0.9 & 0.9 & 8.4 & 1.2 & 14.3 & 1.6 \\
\hline
\end{tabular}



図 13 灘区の新建物倒壊危険度

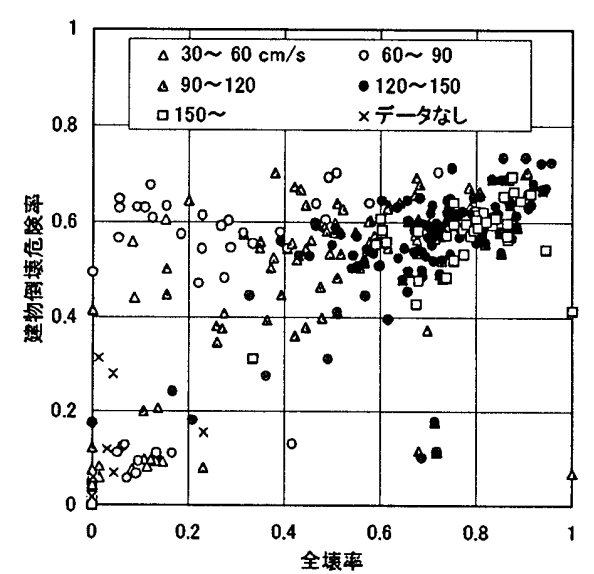

図 14 全壊率と建物倒壊危険率との比較



図 15 全壊棟数と新建物危険棟数との比較
東京都の用いた「危険量」よりも「危険率」の方が名称として適切 であると考え，下記のように建物ごとの倒壊危険率 $P_{k}$ を定義する.

$P_{k}=N_{k} \cdot W_{k l}(k=1-14:$ 建物分類, $l=1-4 ：$ 地盤分類） (4) ここで, $P_{k}$ : 建物ごとの倒壊危険率 $(\%), N_{k}$ : 建物存在比率 $(\%)$, $W_{k l}:$ 危険性ウエイト（\%) である.

このようにして各町丁目内の地盤·建物に応じた建物ごとの倒壊 危険率 $P_{k}$ が求まり，それら全種の建物ごとの倒壊危険率を次式によ って合算したものが各町丁目における建物倒壊危険率 $P_{i}$ となる

$$
P_{i}=\sum_{k-1}^{m} P_{k} \quad(m=14: \text { 建物分類数 })
$$

新建物倒壊危険度 $P$ は，(5) 式により求められた町丁目ごとの新 建物倒壊危険率 $P_{i}$ を大きいものから順に 5 段階に割り当てられたも のである. 算出された灘区の建物倒壊危険率を前節（2）の比率割当 に従ってランク分けし，新建物倒壊危険度として表したものが図 13 である．東京都の方法による建物倒壊危険度（図 5）上比較してみ ると，危険度の高い地域が比較的南側へ移動した。

（3）新建物倒壊危険度と実被害との比較

新しく算出された町丁目ごとの建物倒壊危険率と全壊率の関係を, PGVの大きさによってシンボルを区分し，图 14 に示す. PGV の比 較的小さかった町丁目で，全壊率よりも建物倒壊危険率が高く評価 されていることが読み取れる，危険性ウエイトは灘区全域での全壊 率を基に設定されているため，必ずしも各町丁目ごとに建物倒壊危 険率と全壊率が一致すると注言えないが，图 9 と比べ相関が高くな ったことがわかる．全壊率と建物倒壊危険率に大きな差が生じた地 域を調べてみた結果, その原因として，「町丁目内の棟数が極めて少 ない（1-4 棟)」，「建物棟数密度が高く，古い木造建物で占められて いる地域であるため，算出された建物倒壊危険率は高くなったが， 兵庫県南部地震の際には, 震災の帯から外れたため実被害が小さか った」ことなどが考えられる。

建物の絶対棟数が少ない地域における建物倒壊危険率と全壊率の ずれを補正するため，町丁目内の全建物棟数をかけたもの，すなお ち町丁目ごとの全壊棟数と倒壊危険棟数の関倸を図 15 に示す.この 図においては，図14に比べ，より強い相関が窅える.

以上のことから，ここで算出された建物倒壊危険率は，地域の被 災ポテンシャルを表す上で，有効な指標であると思わ扎る。 


\section{5. 汎用ウェイトの設定手法}

\section{(1) 实被害に基づく確率密度関数}

ここでは，灘区以外の一般的な地域においても建物倒壊危険率お よび新建物倒壊危険度が算定できるよう，信頼性解析 ${ }^{19)}$, 20)を用いた 危険性ウエイトを設定する，信頼性解析には，建物強度確率密度関 数 $R$ と地盤ごとの最大速度の生起確率密度関数 $S$ が必要である. 以 下に, 確率密度関数の求め方についてまとめる.

建物強度確率分布を対数正規分布と仮定し，対数正規確率紙上で 横軸に町丁目単位の PGV, 縱軸に全壊率をプロットし, 回帰直線を 引く.この回帰直線の傾きを $a$, 切片を- $b$ とすれば, 建物強度確率 密度関数

$$
f(x)=\frac{1}{\sqrt{2 \pi} \xi x} \exp \left[-\frac{1}{2}\left(\frac{\ln x-\lambda}{\zeta}\right)^{2}\right] \quad(0<x<\infty)
$$

が得られる.ただし， $\lambda=b / a ， \zeta=1 / a$ であり，それぞれ $\ln x$ の平均值 及び標準偏差となっている.

ここでは， $\lambda_{r}, \zeta_{r}$ の値としてこれまでに構筑した灘区の被害関数 の值 ${ }^{16)}$ を使用した. 図 16 に全壊に対応する建物強度の確率密度関数 を示す. 1971 年以前の木造建物の確率密度分布には大きな差は見ら
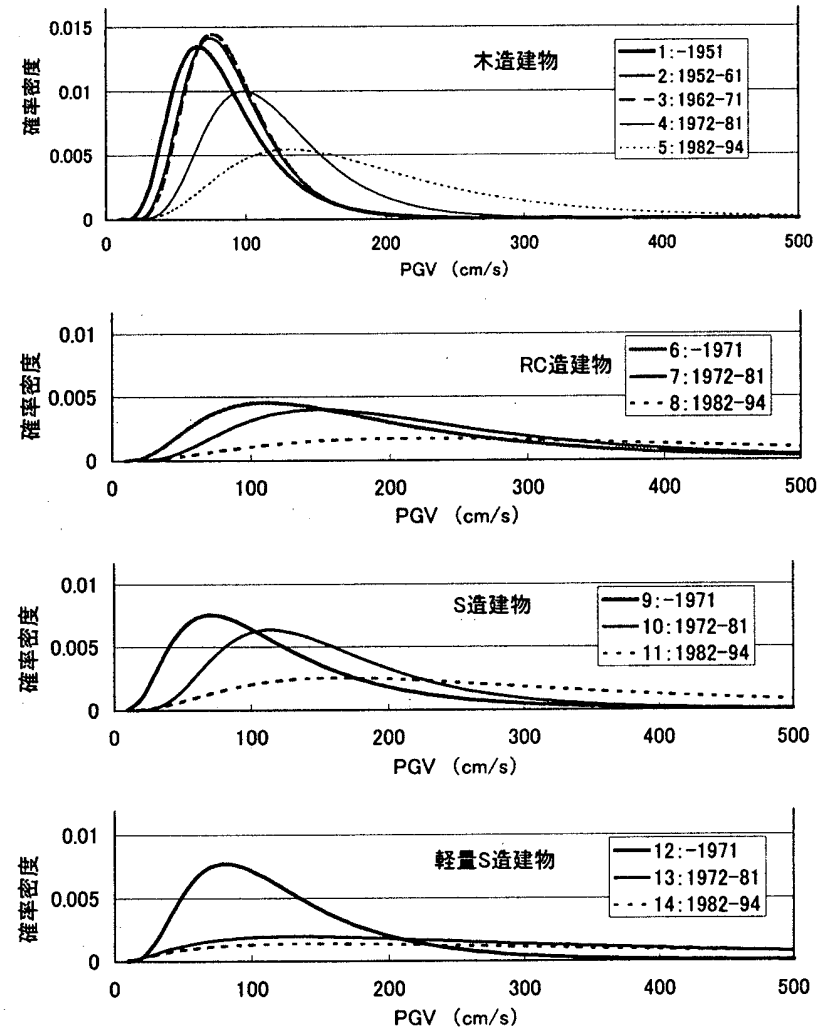

図 16 建物強度の確率密度関数（全壊に対応）



図 17 地盤ごとの PGV 生起確率密度分布関数
れないが, 基本的にどの構造でも新しいものほど, 高い地震動にピ 一クがあり，耐震性が強くなることを表している．また，新しいも のほど分散が大きく，平らな分布形を呈している．同様にして求め た兵庫県南部地震に対する地盤ごとの PGV 生起確率密度分布関数 を図 17 に示す。ピーク時の PGV 指標は山地, 段丘, 罣状地, テル 夕の順に高くなっている．また，摇れの分布は山地，扇状地で比較 的広範に分布しており, 段丘, テルタではピーク値周辺に集中して いる. 各分類のパラメータの値を表 3 に一覧する：山地, 扇状地で はと口值がそれぞれ $0.53,0.33$ と大きくなっており，広範に分布し

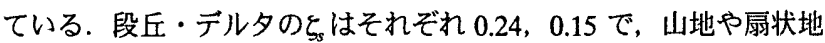
に比べると分布範囲は狭くなっている.

（2）信頼性解析による汎用ウェイト設定手法

建物強度の確率密度関数を $R$, 地形区分ごとの PGV 生起確率密度 関数を $S$ と置くと, 全壊の確率 $P$ ，は，次の式で表される.

$$
P_{f}=P\left(\frac{R}{S}<1\right)
$$

ここで, $Z=R / S$ と置くと, 上式より,

$$
P_{f}=\int_{0}^{1} f_{z}(z) d z
$$

となる. ところで, $R, S$ は正規対数分布を仮定しており（図 18）, その自然対数はその平均值をそれぞれ $\lambda_{r} ， \lambda_{s}$ ，標準偏差を $\xi_{r}, \zeta_{s}$ とす れば, $\ln Z=\ln R-\ln S$ より, $\ln Z$ も正規分布となる.ここで $R$ と が無相関と仮定すれば, $\ln Z$ の平均值及び標準偏差はそれぞれ， $\lambda_{z}=\lambda_{r}-\lambda_{s}, \zeta_{z}=\sqrt{\zeta_{r}^{2}+\zeta_{s}^{2}}$ で与えられる. よって.

$$
\begin{gathered}
P_{f}=\frac{1}{\sqrt{2 \pi} \zeta_{z}} \int_{0} \frac{1}{z} e^{-\frac{1}{2}\left(\frac{\ln z-\lambda_{z}}{\zeta_{z}}\right)^{2}} d z \\
y=\frac{\ln z-\lambda_{z}}{\zeta_{z}} \text { と置換すると, }
\end{gathered}
$$

表 3 確率密度関数のパラメータと全壊率を ほぼ再現するような危険性ウェイト（\%）



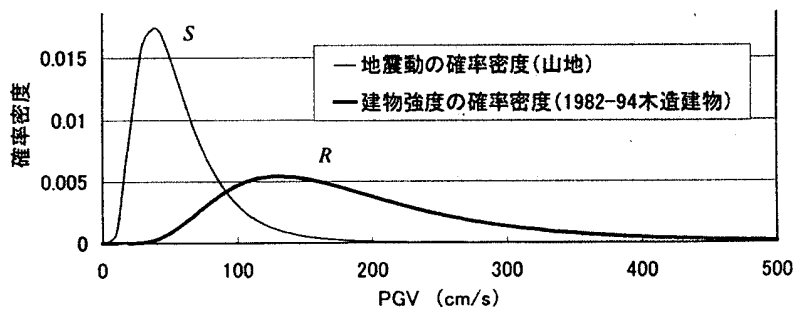

図 18 信頼性解析における被害確率の説明図 


$$
P_{f}=\frac{1}{\sqrt{2 \pi}} \int_{-\infty}^{\frac{\lambda_{z}}{\zeta_{z}}} e^{-\frac{1}{2} y^{2}} d y=1-\Phi\left(\frac{\lambda_{z}}{\zeta_{z}}\right)
$$

となり,あるRと $S$ に対する破壊確率が決定される.ここで, $\Phi\left(\lambda / \zeta_{2}\right)$ は標準正規確率分布関数である.

これを各地盤 $(S)$ ・建物分類 $(R)$ の組み合わせごとに算定した 危険性ウェイトを表 3 に示す. 図 19 のように表 2 の全壊率と比較し たところ, 高い相関（ $\mathrm{R}^{2}=0.94 ）$ が得られ，この方法による全壊率の 再現性が確認された.ここで使用した建物強度の確率密度関数は, 他の地域においても適用できると考えられることから，地域の地盤 特性によるPGV 分布確率密度関数を用意することで, 地域特性に応 じた危険性ウェイトが設定できる.

（3）汎用ウェイト設定手法を用いた新建物倒壊危険度評価法

以上のことと（4）式，（5）式から, 改めて次のような新建物倒壊 危険度評価法を提案する。

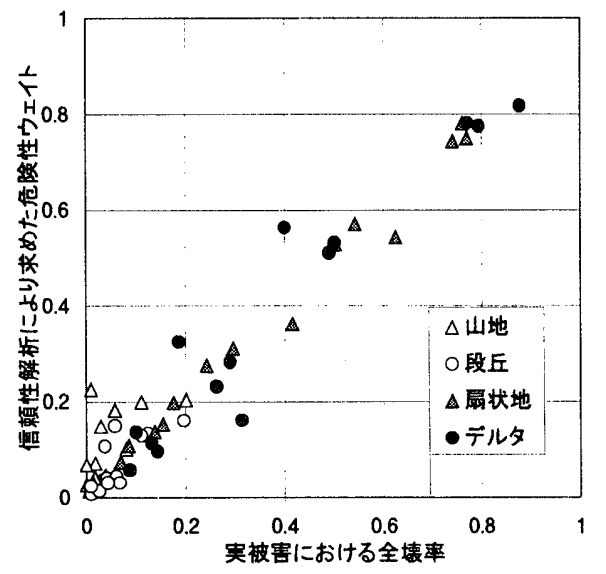

図 19 危険性ウェイトの地盤ごとの再現性の評価

表 4 東京都の地盤分類ごとの PGV 地盤增幅度と 生起確率密度関数のパラメータ值

\begin{tabular}{|c|c|c|c|c|}
\hline $\begin{array}{c}\text { 国土数犆情報の } \\
\text { 地形分類 }\end{array}$ & $\begin{array}{l}\text { 東京都の } \\
\text { 地盤分類 }\end{array}$ & $\begin{array}{l}\text { 最大速度の } \\
\text { 地盤增幅度 }\end{array}$ & $\lambda_{s}$ & $\boldsymbol{\zeta}_{s}$ \\
\hline 山地 & なし & 1.00 & 3.40 & - \\
\hline 乓陵地 & 山地·丘陵 & 1.71 & 3. 94 & 0.10 \\
\hline 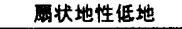 & 沖㯖面1 & 1.48 & 3. 79 & 0.10 \\
\hline 砂磷台地 & 台地1 & 1.62 & 3.88 & 0.10 \\
\hline \multirow{2}{*}{ 火山灰台地 } & 台地2 & \multirow{2}{*}{ 2. 50} & \multirow{2}{*}{ 3. 88} & \multirow{2}{*}{0.10} \\
\hline & 谷底低地2 & & & \\
\hline 三角州性低地（砂） & 沖栈面2 & 2. 39 & 4. 27 & 0.10 \\
\hline \multirow{4}{*}{ 三角州性低地（泥） } & 谷底低地1 & \multirow{4}{*}{ 2. 92} & \multirow{4}{*}{ 4. 47} & \multirow{4}{*}{0.10} \\
\hline & 沖㴋面3 & & & \\
\hline & 沖穕面 4 & & & \\
\hline & 沖栈面5 & & & \\
\hline
\end{tabular}

表 5 本研究のウェイトを東京都に適用した場合の 汎用危険性ウェイト (\%)

\begin{tabular}{|c|c|c|c|c|c|c|c|}
\hline & 丘陵地 & $\begin{array}{c}\text { 厥状地性 } \\
\text { 低地 }\end{array}$ & 础棵台地 & 火山灰台地 & $\begin{array}{l}\text { 三角州性 } \\
\text { 低地(呴) }\end{array}$ & $\begin{array}{l}\text { 三角州性 } \\
\text { 低地(泥) }\end{array}$ \\
\hline \multirow{5}{*}{ 木造 } & -1951 & 16.0 & 9.1 & 13.1 & 46.0 & 41.9 & 60.6 \\
\hline & 1952-61 & 8.6 & 3.9 & 6.5 & 36.9 & 32.4 & 53.6 \\
\hline & $1962-71$ & 7.6 & 3.3 & 5.7 & 35.6 & 31.0 & 52.7 \\
\hline & $1972-81$ & 2.2 & 0.8 & 1.5 & 14.6 & 12.1 & 25.6 \\
\hline & $1982-94$ & 1.0 & 0.4 & 0.7 & 5.6 & 4.7 & 10.0 \\
\hline \multirow{3}{*}{ RC造 } & -1971 & 3.5 & 2.1 & 2.9 & 10.9 & 9.7 & 16.0 \\
\hline & 1972-81 & 0.9 & 0.4 & 0.7 & 4.2 & 3.5 & 7.1 \\
\hline & $1982-94$ & 0.5 & 0.3 & 0.4 & 1.7 & 1.5 & 2.7 \\
\hline \multirow{3}{*}{ S道 } & -1971 & 13.2 & 8.8 & 11.4 & 30.3 & 27.9 & 39.5 \\
\hline & 1972-81 & 1.9 & 0.9 & 1.5 & 9.5 & 8.0 & 15.8 \\
\hline & $1982-94$ & 1.0 & 0.6 & 0.9 & 3.6 & 3.2 & 5.7 \\
\hline \multirow{3}{*}{ 轱S造 } & -1971 & 8.8 & 5.3 & 7.3 & 24.9 & 22.4 & 34.5 \\
\hline & $1972-81$ & 2.7 & 1.9 & 2.4 & 6.2 & 5.7 & 8.4 \\
\hline & 1982-94 & 2.1 & 1.5 & 1.9 & 4.5 & 4.2 & 6.1 \\
\hline
\end{tabular}

(1) 建物倒壊危険率 $P_{i}$ を, 次式で定義する.

$$
P_{i}=\Sigma_{k}\left(N_{k} \cdot W_{k l}\right) \quad(k \text { : 建物分類 ； } l \text { : 地盤分類 }) \quad(11)
$$

ここで, $P_{i}$ : 建物倒壊危険率, $N_{k}$ : 建物存在比率, $W_{k l}$ : 危険性ウェ イトで， $P_{i}$ は，地域の被災ポテンシャルを相対的に表す指標である. 危険性ウェイトは, 建物・地盤分類のマトリクス形式で定義される. (2)地盤分類は地域的な特性に応じて自由に設定することができる. 但し，PGV 生起確率分布が算出できる分類を用いる必要がある。 (3)危険性ウェイト $\left(W_{k l}\right)$ は，信頼性解析による手法で決定する．建 物の全壊確率分布と地盤ごとの $\mathrm{PGV}$ 生起確率分布を用意すること により，地域特性に忍じたウェイト設定が可能である.

(4) (1)で算出された建物倒壊危険率 $P_{i}$ を大きいものから順にランク 付けし，新建物倒壊危険度 $P$ とする. ランク分けの比率割当につい ては, 東京都の方法のように危険度 5 に分類される町丁目を少なく してもよいし，20\%ずつに分類してもよい，地域の大きさに応じた 比率割当が可能である.

このように，地盤の分類に自由度を残したことにより，一般的な 地域で新建物倒壊危険度の算出が可能な評価法となっている.

\section{6. 新建物倒壊危険度評価法による東京都の危険度}

ここでは, 本研究で提案した評価法を東京都に適用し, 評価する. まず危険性ウェイトを設定する際に必要な地盤ごとの PGV の生
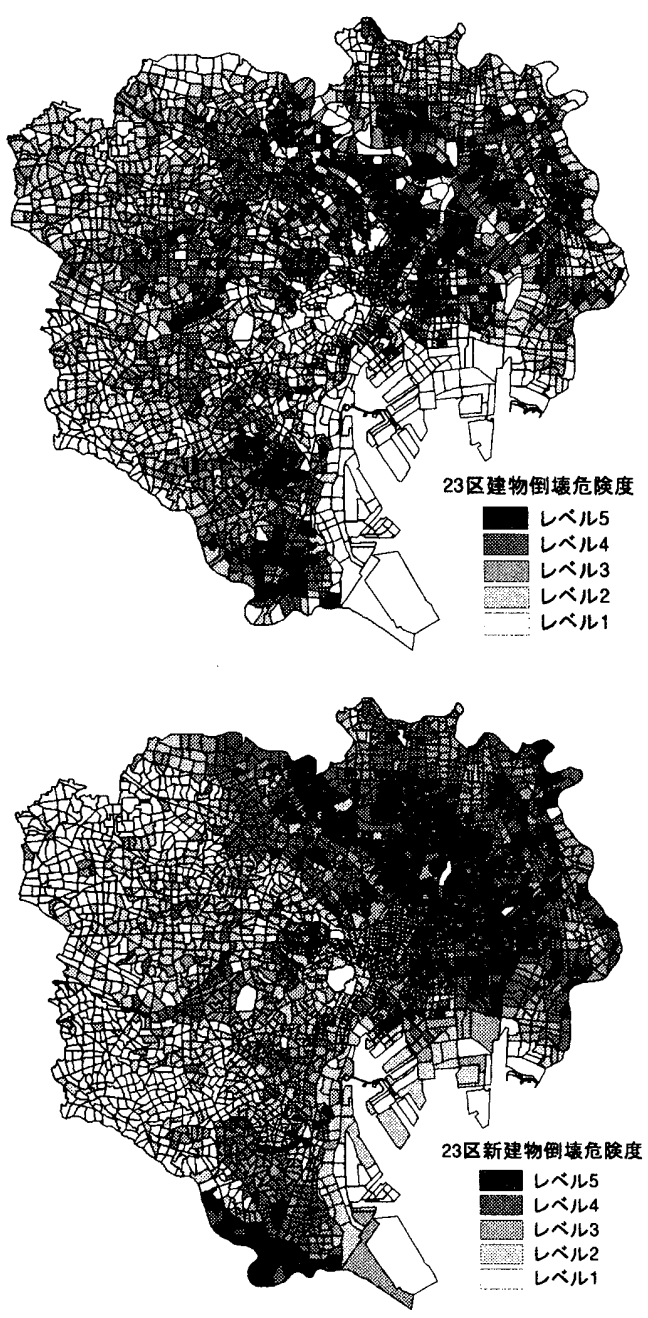

図 20 東京 23 区における建物倒壊危険度の比較 



定する.また国土数值情報の山地における PGV 生起確率密度分布の パラメータとして, 東京都直下地震被害想定 ${ }^{22 .}$. 23)における基盤地 震動レベルの最大速度を $30 \mathrm{~cm} / \mathrm{s}$ とした時の $\lambda_{s}=3.40$ を用いて建物倒 壊危険率と新建物倒壊危険度を求めた（別のパターンとして，兵庫 県南部地震時の灘区山地における $\lambda_{3}=3.90$ の場合でも新建物倒壊危 険度を算定したが, 結果はそれほど違わなかった.）最大速度のと

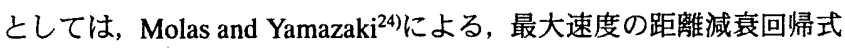
の地域内の変動成分を使用した. これらの数値を表 4 に示す. 前節 で使用した建物分類項目における建物強度確率密度関数のパラメー 夕をそれぞれ $\lambda_{r}, \zeta$ とし, 地盤における PGV 生起確率密度関数の パラメータをそれぞれ $\lambda_{s}, \zeta_{s}$ とすると，(10) 式より危険性ウェイト が求められる（表 5).

以上のデータと 5 節で提案した評価法に基づき, 東京 23 区の新建 物倒壊危険度を算出した. その過程で東京都の建物分類方法で集計 された建物棟数データを使用したため, 木造の 1971 年以前, 1972 年以降，鉄骨造の 1981 年以前，軽量鉄骨造の 1981 年以前の建物に ついては, 東京都の分類と対応する複数の建物分類項目での危険性 ウェイトを平均して用いた. 図 20 に現行の東京都による方法と新評 価法に基づく危険度分布の比較を示す.

東京都の方法は単位面積当たりの被害総量を表しているのと同時 に，3（4）で記したように地盤条件に比べて，建物全体としての棟 数密度が支配的要因であるため, 建物倒壊危険度の高い地域が環状 に分布している. 一方, 本研究の方法では, 地盤の危険性ウェイト が高く, 倒壊可能性の高い木造建物の多い地域（東部下町）で新建 物倒壊危険度が高くなっている. これは本研究の評価法により，建 物強度や地盤の影響がより一層考慮されるようになったためである. 本研究で提案された新建物倒壊危険度は, 東京都の簡易的な方法 を継承する一方で，指標としては異なった意味を持っている．これ は, 地域の被災ポテンシャルを表す指標が実際の地震による建物全 壊率に相当するものであると考えている点にある.

\section{7. まとめ}

本研究では, 東京都の建物倒壊危険度の手法を神戸市灘区に適用 して, 兵庫県南部地震による建物被害との比較を行った. その結果, 建物棟数密度が大きく建物倒壊危険率に影響していることがわかっ た. 次に, 地域の被災ポテンシャルを表す指標は, その地域での地 盤条件を含めた建物倒壊の危険率であると考え, 建物倒壊の危険度 を地震発生時の全壊率に対応する指標として, 信頼性解析に基づく 評価式を構築した。ここで提案した新建物倒壊危険度は, ある地域 の建物存在比率と建物および地盤から決定されるマトリクスタイプ の危険性ウェイトから求められるもので, 灘区の実被害と比較した 結果, 強い相関が確認された.この評価式を用いて各地域の地域特 性を含んだ新建物倒壊危険度を算定することができる. 最後にここ で提案した評価式を用いて東京都の新建物倒壊危険度を評価した. その結果, 東京都の方法では支配的要因であった建物棟数密度の影 響を取り除き，建物強度や地盤の影響を考慮した新建物倒壊危険度 を評価することができた. ただし, 今後この評価法を用いる際には, ここで設定した危険性ウェイトが兵庫県南部地震の経験に基づいて おり,この地震による地震動分布や阪神地域の建物特性の影響を含 んでいることを考慮する必要がある.
今後の課題として, 盛土及び切土地盤, 液状化などの地盤変状発 生による建物被害の取扱いなどがあげられる．また本研究では東京 都の発表した「地震に関する地域危険度測定調査」中の 4 つの危険 度のうち, 最も根幹的な建物倒壊危険度について取り上げたが, 火 災, 人的被害, 避難など他の 3 つの危険度手法や，それらの組み合 わせについても，検討が必要である.

本研究においては, 兵庫県南部地震後に神戸市が調查した建物被 害データ, 東京都都市計画局の GIS データおよび危険度調査データ を利用させていただいた．記して謝意を表する次第である.

\section{若考文献}

1）損害保険料率算定会: 地震被害想定資料集，地震保险調查報告 $28 ， 1998$.

2) 東京都都市計画局 : 地震に関する地域危険度測定調查報告覃（第 4 回）, 1998.

3）東京都都市計画局 : 第 4 回地震に関する地域危険度測定調查 調查結果 活用の手引, 1998.

4）東京都：あなたのまちの地域危険度，1998.

5) 村尾修，山崎文雄：兵庫県南部地震における灘区の建物被害分析，第 24 回地震工学研究発表会論文集, pp.1261-1264, 1997.7 .

6）国土地理院：1/10,000 地震防災土地条件図，1996.

7) 国土地理院：1/25,000 土地条件図，1966.

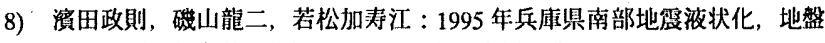
変位及び地盤条件, (財)地震予知総合研究振興会, 1995 .

9）神戸市企画局総合調查課：神戸の地盤，1980.

10) 神戸市 : 神戸市統計要覧 1996, 1996.

11) Murao, O., and Yamazaki, F. : Development of Fragility Curves for Buildings based on Damage Data due to the Hyogoken-Nanbu Earthquake, Proceedings of Asian-Pacific Symposium on Structural Reliability and its Applications (APSSRA 99), pp.259-269, 1999.2.

12）村尾修，山崎文雄 : 兵庫県南部地震の被害分析一その 10 建筑年代を 考虑した木造建物被害に基づく耀区の地霞動分有一，生産研究，Vol. 51, No. 2, pp.17-20, 1999.2 .

13）翠川三郎, 藤本一雄 : 墓石の転倒調查から推定した兵庫県南部地霞の際

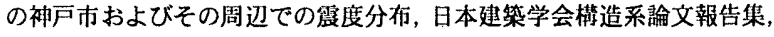
第 490 号, pp.111-118, 1996.12.

14）気象庁: 平成 7 年（1995 年）兵㡷県南部地霞調査報告一災害時自然現象 報告書一，気象仃技術報告，第 119 号，1997。

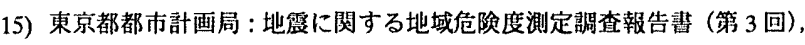
1993.

16）村尾修・山崎文雄: 自治体デー夕に基づく兵阑県南部地霞の建物被害関 数，1999 年度日本建筑学大会（中国）学術講演梗概集 F-1, 日本建築学 会, 1999.

17) 山口直也, 山崎文雄, 若松加寿江 : 兵庫県南部地震における西宮市の建 物被害分析，第 24 回地震工学研究発表会詳演論文集，pp.1237-1240, 1997.7.

18）後藤宽子, 山崎文雄, 若松加寿江, 浅野進一郎 : 兵麻県南部地霞におけ る尼崎市の建物被害分析，第 24 回地震工学研究発表会潇演論文集， pp.1233-1236, 土木学会, 1997.7.

19) 星谷勝：確率論手法による權造解析，店島出版会，1973.

20）中埜良昭，成田恒男：信頼性理論による鉄筇コンクリート造建築物の耐 震安全性に関する研究，日本建築学会㮖造系論文報告集，第 406, pp.37-43, 1989.12 .

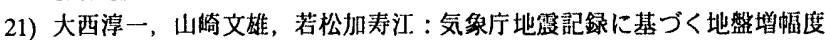
と地形分類との関係, 第 10 回日本地霞工学シンポジウム論文集, pp.909-914, 1998.11.

22) 東京都 : 東京における直下地震の被害想定に関する調査報告蓄, 1997.

23）東京都：東京における直下地震の被害想定に関する調查報告輩（被害想 定手法編)， 1997.

24) G. L. Molas, F. Yamazaki : Attenuation of Earthquake Ground Motion in Japan, Including Deep Focus Events, Bulletin of the Seismological Society of America, 85,5 , pp.1343-1358, 1995. 10.

（1999年4月10日原稿受理，1999年 8 月27日採用決定） 